\title{
PERBANDINGAN SIKAP MENGGUNAKAN KOMPUTER ANTARA DOSEN DAN ANGGOTA E-LEARNING COMMUNITY
}

Fidelis Jacklyn Adella, Elisabeth Rukmini

Fakultas Kedokteran Universitas Katolik Atma Jaya Jakarta

\begin{abstract}
Background: E-learning community (eLC) of the School of Medicine Atma Jaya Catholic University of Indonesia consisted of twelve students. eLC trained lecturers about e-learning in personal or small group format. This study aimed to compare the differences between the development of computer-related attitude between lecturers and e-learning community members upon the service from e-learning community for lecturers.

Method: This research was an experimental quantitative and qualitative study. Subjects were 12 students of eLC and 32 lecturers who received eLC's services. The quantitative data was collected through questionnaires of the Computer Anxiety Rating Scale (CARS) and Computer Self-Efficacy (CSE). The qualitative data was collected through focus group discussion and in-depth interviews. CARS and CSE data were collected four times: (1) prior to the eLC trainings, (2) right after the eLC first training, (3) after the second training of eLC, and (4) right after one month of the last training from eLC. Data analysis was conducted using Friedman test, Mann-Whitney test. Qualitative data analysis were performed using content analysis.

Results: There was a significant decrease from the score of CARS 1 to the score of CARS 4 for the eLC members $(p=0,045)$. Results of CSE for eLC members showed no significant differences across the data collection. For faculty members, the significant differences were found between CARS 3 and CARS 4 ( $p=0,014)$. CSE scores of faculty members showed no significant differences. Comparison of CARS and CSE between faculty members and eLC members showed no significant differences. The qualitative data analysis showed some important aspects found in both of the groups. There are communication, interaction, the importances of eLC trainings, as well as suggestions to both of the groups about e-learning. Subjects' opinions were divided into two groups: one who experienced positive changes in their computerrelated attitude and one who did not experience any changes.

Conclusion: Faculty members found that eLC were important in relation to e-learning training for lecturers. Students strongly agreed that being the member of eLC made him/her had a great opportunity to closely communicate to their lecturers. The faculty members' anxiety level of computer using was low; on the other hand, their awareness of computer technology was good enough. The institution should employ this opportunity to apply e-learning more seriously and extensively.
\end{abstract}

Keywords: e-learning, computer anxiety, computer self-efficacy, lecturer, tutoring

\section{ABSTRAK}

Latar Belakang: E-learning community (eLC) Fakultas Kedokteran Universitas Katolik Indonesia Atma Jaya beranggota 12 mahasiswa untuk melayani dosen dengan pelatihan e-learning secara perorangan atau kelompok kecil. Tujuan penelitian ini mengetahui perbandingan antara perkembangan sikap dosen yang dilayani oleh eLC dan anggota eLC terhadap penggunaan komputer.

Metode: Desain penelitian berupa eksperimentasi kuantitatif dan kualitatif. Subyek adalah 12 mahasiswa eLC dan 32 dosen penerima layanan. Data kuantitatif berasal dari kuesioner Computer Anxiety Rating Scale (CARS) dan Computer Self-Efficacy (CSE), data kualitatif dari focus group discussion (FGD) dan in-depth interview. CARS dan CSE diambil empat kali: (1) sebelum eLC berkarya, (2) tepat setelah bantuan pertama, (3) setelah bantuan lanjutan, dan (4) tepat satu bulan setelah bantuan terakhir eLC. Analisis data menggunakan uji Friedman dan Mann-Whitney, serta analisis konten untuk data kualitatif.

Korespondensi: elisabeth.rukmini@atmajaya.ac.id 
Hasil: Terjadi penurunan bermakna dari skor CARS 1 ke skor CARS 4 untuk anggota eLC $(p=0,045)$. Hasil CSE anggota eLC tidak menunjukkan perbedaan signifikan. Untuk dosen, perbedaan bermakna terjadi antara CARS 3 dan CARS $4(p=0,014)$. CSE dosen tidak menunjukkan perbedaan signifikan. Perbandingan CARS dan CSE antara dosen dan mahasiswa menunjukkan tiadanya perbedaan signifikan. Analisis data kualitatif menunjukkan aspek komunikasi, interaksi, pentingnya bantuan eLC, serta masukan bermanfaat bagi kedua pihak terkait $e$ learning. Pendapat subyek terbagi dua, yang merasakan perubahan persepsi lebih baik setelah pengalaman belajar dari eLC dan yang tidak merasakan adanya perubahan persepsi.

Kesimpulan: eLC dianggap penting bagi dosen. Anggota eLC merasakan manfaat berkomunikasi dengan dosen. Tingkat kekawatiran dosen terhadap penggunaan komputer rendah, sedangkan kesadaran penggunaan teknologi komputer para dosen sudah cukup baik. Hal ini merupakan peluang bagi institusi untuk menerapkan e-learning secara lebih serius.

Kata kunci: e-learning, computer anxiety, computer self-efficacy, dosen, tutoring

\section{PENDAHULUAN}

Survei di Amerika serikat menyatakan bahwa 75\% dari 650 orang mahasiswa setuju penggunaan IT membantu mereka lebih aktif dalam belajar, sedangkan $72 \%$ setuju penggunaan komputer membantu mereka lebih memahami materi yang sebelumnya sulit dimengerti. ${ }^{1}$ Ini merupakan bukti bahwa metode belajar tradisional perlahan tergantikan oleh pembelajaran berbasis komputer. Sayangnya, hal ini kerap dirintangi masalah antargenerasi. Banyak pengajar berasal dari generasi yang tidak terbiasa menggunakan fasilitas komputer. Pada umumnya pengajar seperti ini perlu penyesuaian diri sebelum dapat mengimplementasikan teknik pembelajaran berbasis komputer.

Hal yang sama terjadi di lingkungan Universitas Katolik Indonesia Atma Jaya. Fasilitas electronic learning (e-learning) sudah lama disediakan, antara lain melalui penggunaan power point presentation, proyektor, perpustakaan online, dan Moodle ${ }^{\mathrm{TM}}$. Namun, belum semua dosen memanfaatkan hal ini. Padahal, menurut suatu penelitian mengenai harapan terhadap e-learning di UAJ menunjukkan baik mahasiswa maupun dosen optimis bahwa UAJ dapat disebut sebagai kampus e-learning dalam kurun waktu 2-5 tahun ke depan. ${ }^{2}$

Penelitian ini diawali dengan dibentuknya suatu e-learning community (eLC) yang terdiri dari para mahasiswa yang fasih menggunakan komputer. eLC ini akan membagi ilmunya dan melayani para dosen di FKUAJ yang membutuhkan bantuan terkait e-learning. Tujuan akhir dari proses ini adalah terwujudnya UAJ sebagai kampus e-learning dan meningkatnya kualitas proses belajarmengajar antara dosen dan mahasiswa. Melalui program eLC ini dapat dilihat bagaimana perkembangan sikap dosen yang diberi pelayanan terhadap komputer. Resistensi dosen mempelajari teknologi terutama dikarenakan keengganan dosen mempelajari teknologi yang dirasakan berkembang sangat cepat dan melebihi kecepatan belajarnya. ${ }^{2}$ Diharapkan resistensi ini dapat teratasi oleh dibentuknya eLC.

Rekam jejak berkurangnya resistensi dosen ini dapat diukur selama perjalanan karya eLC melalui alat ukur dan evaluasi program. Perkembangan sikap dosen ini akan disandingkan dengan perkembangan sikap dari anggota eLC sebagai perbandingan. Bermakna atau tidaknya proses berkurangnya resistensi dosen yang disandingkan dengan perkembangan resistensi anggota eLC dapat menjadi penilaian efektivitas program eLC. Penelitian ini bertujuan untuk mengetahui perbandingan antara perkembangan sikap dosen dan anggota eLC terhadap penggunaan komputer. Hal tersebut dilihat melalui perubahan skor Computer Anxiety Rating Scale (CARS) dan skor Computer Self-Efficacy (CSE).

Dalam bukunya yang berjudul E-Learning by Design, Horton $^{3}$ mendefinisikan e-learning sebagai penggunaan teknologi elektronik untuk menciptakan pengalaman belajar. Definisi ini sangat luas dan memiliki implikasi bahwa e-learning tidak terbatas pada satu jenis metode saja, juga tidak selalu berarti suatu kelas pembelajaran. Elearning termasuk dalam metode-metode yang mencakup mulai dari penampilan gambar menggunakan komputer 
sam pai universitas online. Konten materi e-learning sangat bervariasi, contohnya audio, video, gambar, tulisan dan buku elektronik.

Pada umumnya ditemukan bahwa pembelajaran yang menerapkan e-learning lebih efektif daripada pembelajaran tradisional tanpa media elektronik, seperti yang ditemukan oleh Lau dan Bates ${ }^{4}$ yang merangkumkan berbagai penelitian mengenai penerapan e-learning. Mereka menemukan bahwa penerapan e-learning pada undergraduate medical students memudahkan proses pembelajaran dalam kelas besar dan membantu penyamaan persepsi. ${ }^{4}$ Studi lain juga mendukung temuan tersebut dengan menyatakan bahwa e-learning dapat digunakan untuk membantu pembelajaran dalam universitas yang memiliki jumlah mahasiswa yang besar sehingga sulit mendapatkan waktu berinteraksi yang cukup dengan instruktur/dosen. ${ }^{5}$ Mahasiswa yang diberi fasilitas e-learning dapat meraih skor lebih tinggi daripada mahasiswa kelompok kontrol. ${ }^{6,7}$

Di fakultas kedokteran seringkali terdapat topik-topik yang secara konsep sulit dipahami. Selain itu, pendidikan kedokteran juga mengharuskan mahasiswanya menguasai berbagai keterampilan yang tentunya sulit bila hanya dipelajari dari buku teks atau temu singkat dengan instruktur. Kendala-kendala tersebut dapat diatasi oleh e-learning. Aplikasi e-learning pada topik yang dianggap sulit secara konseptual, misalnya pada leukemia, membuktikan kontribusi nilai nilai yang lebih baik secara signifikan daripada kelompok control. ${ }^{8}$ E-learning bermanfaat dalam pendidikan keterampilan (skills), seperti dalam basic life supportdengan automated external defibrillator (BLS-AED). ${ }^{9}$ Secara keseluruhan, e-learning meningkatkan pemahaman mahasiswa mengenai materi pembelajaran (baik berupa konsep maupun keterampilan) sehingga membantu dalam proses penilaian. Sikap, minat, dan motivasi belajar mahasiswa akan materi pembelajaran juga meningkat pada kelompok-kelompok yang diberi modul e-learning. ${ }^{5,7,8}$

Di UAJ, 72\% dari 167 mahasiswa Fakultas Kedokteran dan Fakultas Teknobiologi merasa penerapan e-learning di kampus "sangat perlu". Sebanyak 37\% mahasiswa merasa UAJ perlu menjadi kampus yang berbasis e-learning pada tahun 2012 (tahun penelitian tersebut dilakukan), sedangkan sisanya memberi jawaban yang bervariasi antara satu sampai lima tahun lagi. ${ }^{2}$
Meskipun e-learning secara keseluruhan tampaknya membantu proses pembelajaran, tetapi perlu ditekankan pentingnya kontrol pada pembelajar secara mandiri. Levinson ${ }^{10}$ dalam penelitiannya menemukan bahwa elearning yang dikontrol oleh pembelajar kurang efektif dibanding programme-controlled e-learning. Hal ini berarti materi e-learning yang telah dikemas khusus untuk proses interaksi pembelajaran lebih unggul dibanding materi "mentah" yang bebas diakses mahasiswa seperti buku digital atau gambar-gambar yang diunduh dari internet. Dengan adanya programme-controlled e-learning, pembelajaran mandiri mahasiswa menggunakan e-leaming lebih terarah dan efektif.

Programme-controlled e-learning yang memerlukan materi yang sudah dikemas mengimplikasikan bahwa e-learning untuk mahasiswa bertumpu pada pengetahuan dan kemampuan instruktur atau dosen dalam menyusun materi e-learning. ${ }^{11}$ Masalah muncul ketika para dosen tersebut tidak familiar dengan konsep e-learning atau dengan penggunaan komputer.

Istilah "digital immigrants" dan "digital natives" pertama diungkapkan oleh Prensky ${ }^{12}$ untuk menggambarkan perbedaan antara keakraban mahasiswa versus dosen dengan teknologi dengan teknologi. Menurutnya, sebagai “digital immigrants", dosen dapat mempelajari teknologi, tetapi mereka memiliki kebiasaan dan ketakutan dari masa-masa pra-teknologi. Sementara itu, mahasiswa yang merupakan "digital natives" mudah beradaptasi dengan perkembangan teknologi. ${ }^{13}$

Teknologi baru dengan fitur yang rumit atau fitur yang terlalu sedikit juga membuat orang dewasa enggan mempelajarinya karena kawatir atau takut salah. ${ }^{14,15}$ Halhal itu dapat terjadi bila kemampuan dan pengetahuan orang tersebut akan teknologi tidak cukup. Hambatan penguasaan teknologi menyebabkan keengganan menggunakan teknologi. Kedua hal tersebut dapat tercermin antara lain dalam tingkat kekhawatiran dan tingkat kemampuan menggunakan komputer maupun internet.

Di UAJ ditemukan bahwa 80\% (40 orang) dosen merasa UAJ perlu berbasis e-learning dalam waktu dua tahun lagi, namun, focus group discussion yang dilakukan antara partisipan dosen dan mahasiswa membuktikan bahwa para dosen merasa kurang berminat mengimplementasi- 
kan e-learning dengan berbagai alasan. Alasan-alasan tersebut di antaranya sudah terbiasa dengan metode mengajar tradisional, kurangnya niat membuat materi, kesibukan pribadi, dan pandangan tentang e-learning sebagai sesuatu yang kompleks. ${ }^{2}$ Dua data yang bertolak belakang tersebut dapat dijelaskan oleh Buda dalam penelitiannya, yaitu bahwa ketertarikan para pengajar akan teknologi baru dan metode-metode yang berkaitan dengan teknologi baru tersebut hanya terbatas pada ide saja dan jarang diterapkan dalam praktek sehari-hari. ${ }^{16}$

Perbedaan "status" antara dosen dan mahasiswa (para "digital immigrants" dan "digital natives") menciptakan kesenjangan yang menghambat komunikasi efektif antara dosen dengan mahasiswa dalam proses pembelajaran berkonteks e-learning. Hal ini berujung pada sulitnya transisi UAJ menjadi kampus berbasis e-learning. Salah satu pihak, mahasiswa atau dosen, perlu beradaptasi dengan cara salah satu pihak itu dalam proses belajar mengajar. Sayangnya, kemungkinan pihak mahasiswa beradaptasi dengan pihak dosen sangatlah kecil. Observasi dari berbagai fenomena migrasi kultural telah menunjukkan bahwa orang-orang yang lahir di era kultural baru dapat mempelajari bahasa baru mereka dengan cepat, tetapi menolak menggunakan yang lama. ${ }^{17}$ Oleh karena itu, dosen adalah pihak yang mau tidak mau harus sanggup beradaptasi dengan kemajuan teknologi ini.

Dosen sebenarnya menunjukkan minat untuk memperdalam ilmu mereka di bidang IT asalkan dibimbing sesuai konteks dan kemampuannya. ${ }^{2}$ Mengetahui hal tersebut, sangat mungkin bagi kita untuk menyediakan bantuan dalam bentuk yang diharapkan para dosen dengan memanfaatkan kesenjangan antara "digital natives" dan "digital immigrants". Mahasiswa sebagai "digital natives" dapat menjadi tutor bagi dosen. Kegiatan tutoring telah terbukti dapat membantu perkembangan tutor dan tutee..$^{18}$ Bantuan dari mahasiswa untuk dosen juga diharapkan bermanfaat, sehingga di masa yang akan datang elearning semakin dapat diimplementasikan.

\section{METODE}

Desain penelitian merupakan penelitian eksperimental kuantitatif dan kualitatif. Data kuantitatif diperoleh melalui kuesioner. Metode kuantitatif ini didukung oleh metode kualitatif dengan cara focus group discussion dan in-depth interview. Sampel penelitian adalah seluruh anggota eLC dan seluruh dosen yang menerima pelayanan. Total anggota eLC 12 mahasiswa, sedangkan jumlah dosen yang menerima pelayanan adalah 32 orang, tetapi hanya 11 orang yang diambil datanya sebanyak empat kali. Dosen lainnya disertakan datanya sebagai data deskriptif saja, sedangkan satu dosen menolak mengisi kuesioner terakhir sehingga tereksklusi.

Sepanjang perjalanan program diadakan penyegaran dengan materi clicker, animasi, Zotero, dan Moodle ${ }^{\mathrm{TM}}$. Bahan Prezi dipelajari sendiri oleh masing-masing anggota. Bahan animasi dipelajari dengan narasumber, tetapi tidak dilatihkan kepada dosen karena dipandang terlalu sulit.

Pengukuran kuantitatif menggunakan kuesioner Computer Anxiety Rating Scale (CARS) ${ }^{15}$ dan kuesioner Computer Self-Efficacy (CSE). ${ }^{16,17}$ Pengambilan data dilakukan sebanyak empat kali, yaitu sebelum e-learning community berkarya, tepat setelah bantuan pertama, setelah bantuan lanjutan, dan tepat satu bulan setelah bantuan terakhir dari eLC. Data kualitatif dosen diambil menggunakan in-depth interview yang dilaksanakan setelah pelatihan terakhir. Data kualitatif anggota eLC diambil dengan FGD dan in-depth interview.

Tahap analisis data kuantitatif terdiri dari dua tahapan. Tahap pertama berupa analisis masing-masing perubahan skor anggota eLC dan skor dosen (CARS dan CSE). Tahap kedua adalah analisa perbandingan antara perubahan skor dosen dengan perubahan skor anggota eLC. Sementara itu, analisis data kualitatif dibagi menjadi persiapan analisis dan tahap analisis. Persiapan analisis adalah proses transkripsi data rekaman audio menjadi data tertulis verbatim. Analisa data kualitatif menggunakan analisiss konten oleh peneliti utama beserta empat orang inter-rater yang menghasilkan data yang telah tergolongkan dalam kode-kode (tema).

\section{HASIL DAN PEMBAHASAN}

\section{Hasil Penelitian Kuantitatif}

Deskriptif skor CARS dan CSE anggota eLC pada setiap pengambilan data dapat dilihat pada tabel 1 . 
Tabel 1. Tabel deskriptif skor CARS dan CSE anggota E-learning Community

\begin{tabular}{cccccc} 
No. & Rincian Skor & $\begin{array}{c}\text { Nilai Rerata } \pm \text { Simpangan } \\
\text { Baku }\end{array}$ & $\begin{array}{c}\text { IK 95\% Lower-Upper } \\
\text { Bound }\end{array}$ & Median & Modus \\
1. & CARS 1 eLC & $38,83 \pm 8,983$ & $33,13-44,54$ & 37,00 & 37,00 \\
2. & CARS 2 eLC & $37,33 \pm 9,277$ & $31,44-43,23$ & 36,00 & 23,00 \\
3. & CARS 3 eLC & $35,00 \pm 9,045$ & $29,25-40,75$ & 35,00 & 30,00 \\
4. & CARS 4 eLC & $34,33 \pm 10,543$ & $27,63-41,03$ & 30,50 & 28,00 \\
5. & CSE 1 eLC & $119,25 \pm 14,085$ & $110,30-128,20$ & 118.50 & 116,00 \\
6. & CSE 2 eIC & $119,92 \pm 14,519$ & $110,69-129,14$ & 116,50 & 114,00 \\
7. & CSE 3 eLC & $122,00 \pm 15,202$ & $112,34-131,66$ & 118,00 & 117,00 \\
8. & CSE 4 eLC & $127,75 \pm 14,467$ & $118,56-136,94$ & 129,50 & 121,00 \\
\hline
\end{tabular}

Dari tes normalitas data anggota eLC tidak normal, kecuali pada pengambilan data CSE kedua $(p=0,043)$, oleh karena itu digunakan tes Friedman. Hasil uji Friedman menunjukkan bahwa paling tidak ada satu pasang variabel berhubungan yang perbedaannya bermakna. Untuk mengetahui pasangan tersebut dilakukan analisis post-hoc dengan tes Wilcoxon. Dari hasil tes Wilcoxon diketahui pasangan dengan perbedaan bermakna adalah data CARS 4 dan CARS 1 eLC (Tabel 2)

Tabel 2. Tabel tes Post-Hoc Wilcoxon data CARS anggota E-Learning Community

\begin{tabular}{lccc} 
No. & Rincian Skor & $\begin{array}{c}\text { Perbedaan nilai } \\
\text { rerata }\end{array}$ & Nilai p \\
1. & CARS 2 eLC - CARS 1 eLC & $-1,50$ & 0,345 \\
2. & CARS 3 eLC - CARS 2 eLC & $-2,33$ & 0,077 \\
3. & CARS 4 eLC - CARS 3 eLC & $-0,67$ & 0,167 \\
4. & CARS 3 eLC - CARS 1 eLC & -3.83 & 0,068 \\
5. & CARS 4 eLC - CARS 1 eLC & -4.50 & 0,045 \\
6. & CARS 4 eLC - CARS 2 eLC & $-3,00$ & 0,054 \\
\hline
\end{tabular}

Mean skor CARS 1 anggota eLC adalah 38,83 dan skor CARS 4 eLC adalah 34,33. Dapat diambil kesimpulan bahwa terjadi penurunan yang bermakna dari skor CARS 1 ke CARS 4 anggota eLC.

Tes Friedman data CSE anggota e-learning community menunjukkan $\mathrm{p}>0,05$ yang berarti tidak ada perbedaan yang bermakna antara skor pada keempat pengambilan data CSE untuk anggota eLC.

Nilai CARS dan CSE dosen untuk keempat pengambilan data dapat dilihat pada tabel 3. 
Tabel 3. Tabel deskriptif skor CARS dan CSE dosen

\begin{tabular}{cccccc} 
No. & Rincian Skor & $\begin{array}{c}\text { Nilai Rerata } \pm \text { Simpangan } \\
\text { Baku }\end{array}$ & $\begin{array}{c}\text { IK 95\% Lower-Upper } \\
\text { Bound }\end{array}$ & Median & Modus \\
1. & CARS 1 dosen & $38,36 \pm 7,243$ & $33,50-43,23$ & 37,00 & 31,00 \\
2. & CARS 2 dosen & $36,36 \pm 7,632$ & $31,24-41,49$ & 37,00 & 24,00 \\
3. & CARS 3 dosen & $37,36 \pm 6,562$ & $32,96-41,77$ & 40,00 & 40,00 \\
4. & CARS 4 dosen & $34,82 \pm 5,689$ & $31,00-38,64$ & 37,00 & 37,00 \\
5. & CSE 1 dosen & $118,09 \pm 13,179$ & $109,24-126,94$ & 116,00 & 116,00 \\
6. & CSE 2 dosen & $119,55 \pm 16,170$ & $108,68-130,41$ & 116,00 & 92,00 \\
7. CSE 3 dosen & $118,82 \pm 10,572$ & $111,72-125,92$ & 116,00 & 116,00 \\
8. & CSE 4 dosen & $124,64 \pm 13,706$ & $115,43-133,84$ & 116,00 & 116,00 \\
\hline
\end{tabular}

Hasil uji normalitas menunjukkan data CARS dan CSE dosen tidak terdistribusi normal. Oleh karena itu, analisis data dosen menggunakan tes Friedman. Hasil tes Friedman data CARS menunjukkan ada perbedaan bermakna pada paling tidak satu pasang variabel. Dari tes post-hoc menggunakan Wilcoxon diketahui bahwa pasangan tersebut adalah pengambilan data CARS 4 dan CARS 3 (Tabel 4).

Tabel 4. Tabel tes Post-Hoc Wilcoxon data CARS dosen

\begin{tabular}{lccc} 
No. & Rincian Skor & $\begin{array}{c}\text { Perbedaan } \\
\text { nilai rerata }\end{array}$ & Nilai p \\
\hline 1. & CARS 2 dosen - CARS 1 dosen & $-2,00$ & 0,102 \\
2. & CARS 3 dosen - CARS 2 dosen & 1,00 & 0,400 \\
3. & CARS 4 dosen - CARS 3 dosen & $-2,54$ & 0,014 \\
4. & CARS 3 dosen - CARS 1 dosen & $-1,00$ & 0,384 \\
5. CARS 4 dosen - CARS 1 dosen & -3.54 & 0,102 \\
6. & CARS 4 dosen - CARS 2 dosen & -1.54 & 0,100 \\
\hline
\end{tabular}

Mean data CARS 3 dosen adalah 37,36 sedangkan data CARS 4 dosen adalah 34,82. Dapat ditarik kesimpulan bahwa terjadi penurunan skor CARS yang bermakna dari skor CARS 3 ke CARS 4 dosen.

Hasil tes Friedman data CSE dosen menunjukkan $\mathrm{p}>$ 0,05 yang berarti tidak ada perbedaan bermakna antara pengambilan-pengambilan nilai CSE dosen.
Pada analisis data tahap kedua perubahan skor antar pengambilan data milik anggota eLC dan perubahan skor antar pengambilan data dosen dibandingkan untuk mengetahui apakah ada perbedaan yang bermakna. Data deskriptif tampak pada tabel 5 dan 6 . 
Tabel 5. Tabel deskriptif perubahan skor CARS dan CSE anggota E-Learning Community

\begin{tabular}{lccccc} 
No. & Rincian Skor & $\begin{array}{c}\text { Nilai Rerata } \pm \\
\text { Simpangan Baku }\end{array}$ & $\begin{array}{c}\text { IK 95\% Lower-Upper } \\
\text { Bound }\end{array}$ & Median & Modus \\
\hline 1. & Perubahan 1 CARS eLC & $(-1,50) \pm 4,796$ & $(-4,55)-1,55$ & $-1,50$ & 3,00 \\
2. & Perubahan 2 CARS eLC & $(-2,33) \pm 4,097$ & $(-4,94)-0,27$ & $-2,50$ & $-2,00$ \\
3. & Pcrubahan 3 CARS cLC & $(-0,67) \pm 6,840$ & $(-5,01)-3,68$ & $-2,50$ & $-6,00$ \\
4. & Perubahan 1 CSE eLC & $0,67 \pm 6,959$ & $(-3,75)-5,09$ & 0,50 & 0,00 \\
5. & Perubahan 2 CSE eLC & $2,08 \pm 9,219$ & $(-3,77)-7,94$ & 2,00 & 0,00 \\
6. & Perubahan 3 CSE eLC & $5,75 \pm 9,790$ & $(-0,47)-11,97$ & 5,50 & 0,00 \\
\hline
\end{tabular}

Tabel 6. Tabel deskriptif perubahan skor CARS dan CSE dosen

\begin{tabular}{|c|c|c|c|c|c|}
\hline No. & Rincian Skor & $\begin{array}{c}\text { Nilai Rerata } \pm \text { Simpangan } \\
\text { Baku }\end{array}$ & $\begin{array}{c}\text { IK 95\% Lower-Upper } \\
\text { Bound }\end{array}$ & Median & Modus \\
\hline 1. & $\begin{array}{l}\text { Perubahan } 1 \text { CARS } \\
\text { dosen }\end{array}$ & $(-2,00) \pm 6,812$ & $(-6,58)-2,58$ & $-4,00$ & $-5,00$ \\
\hline 2. & $\begin{array}{l}\text { Perubahan } 2 \text { CARS } \\
\text { dosen }\end{array}$ & $1,00 \pm 6,033$ & $(-3,05)-5,05$ & 0,00 & 0,00 \\
\hline 3. & $\begin{array}{l}\text { Perubahan } 3 \text { CARS } \\
\text { dosen }\end{array}$ & $(-2,25) \pm 2,770$ & $(-4,41)-(-0,68)$ & $-3,00$ & $-3,00$ \\
\hline 4. & $\begin{array}{l}\text { Perubahan } 1 \text { CSE } \\
\text { dosen }\end{array}$ & $1,45 \pm 12,699$ & $(-7,08)-9,99$ & 0,00 & $-6,00$ \\
\hline 5. & $\begin{array}{l}\text { Perubahan } 2 \mathrm{CSE} \\
\text { dosen }\end{array}$ & $(-0,73) \pm 11,490$ & $(-8,45)-6,99$ & 0,00 & 0,00 \\
\hline 6. & $\begin{array}{l}\text { Perubahan } 3 \text { CSE } \\
\text { dosen }\end{array}$ & $5,82 \pm 9,786$ & $(-0,76)-12,39$ & 2,00 & 0,00 \\
\hline
\end{tabular}

Perubahan skor tersebut kemudian dibandingkan dengan tes Mann-Whitney U. Nilai p untuk semua kelompok lebih besar dari 0,05 ( $p>0,05)$. Dapat ditarik kesimpulan bahwa perbedaan skor CARS dan CSE pertama, kedua, dan ketiga tidak berbeda antara kelompok eLC dengan kelompok dosen.
Para dosen yang tidak mengikuti pelatihan secara lengkap (kurang dari dua kali pelatihan atau menolak mengisi kuesioner) datanya diambil untuk digunakan secara deskriptif (tabel 7) 
Tabel 7. Tabel deskriptif skor CARS dan CSE dosen yang tidak lengkap

\begin{tabular}{|c|c|c|c|c|c|}
\hline No. & Rincian Skor & $\begin{array}{c}\text { Nilai Rerata } \pm \text { Simpangan } \\
\text { Baku }\end{array}$ & $\begin{array}{c}\text { IK 95\% Lower-Upper } \\
\text { Bound }\end{array}$ & Median & Modus \\
\hline 1. & $\begin{array}{l}\text { CARS } 1 \text { data dosen } \\
\text { tidak lengkap }\end{array}$ & $37,95 \pm 8,661$ & $33,92-41,98$ & 39,00 & 39,00 \\
\hline 2. & $\begin{array}{l}\text { CARS } 2 \text { data dosen } \\
\text { tidak lengkap }\end{array}$ & $35,35 \pm 7.869$ & $31,67-39,03$ & 37,50 & 23,00 \\
\hline 3. & $\begin{array}{l}\text { CARS } 3 \text { data dosen } \\
\text { tidak lengkap }\end{array}$ & $38,50 \pm 6,605$ & $35,41-41,59$ & 38,50 & 41,00 \\
\hline 4. & $\begin{array}{l}\text { CSE } 1 \text { data dosen } \\
\text { tidak lengkap }\end{array}$ & $114,00 \pm 15,005$ & $106,98-121,02$ & 111,50 & 101,00 \\
\hline 5. & $\begin{array}{l}\text { CSE } 2 \text { data dosen } \\
\text { tidak lengkap }\end{array}$ & $117,25 \pm 14,832$ & $110,31-124,19$ & 114,00 & 114,00 \\
\hline 6. & $\begin{array}{l}\text { CSE } 3 \text { data dosen } \\
\text { tidak lengkap }\end{array}$ & $119,05 \pm 11,213$ & $113,80 \cdot 124,30$ & 116,00 & 111,00 \\
\hline
\end{tabular}

Pada tabel tersebut pengambilan data 1 adalah sebelum menerima pelatihan, data 2 setelah menerima pelatihan pertama, dan data 3 adalah satu bulan setelah menerima pelatihan pertama tersebut.

\section{Hasil Penelitian Kualitatif}

Hasil penelitian kualitatif merupakan hasil analisis dari opini kelompok anggota eLC dan kelompok dosen. Hasil FGD dan wawancara anggota e-learning community terbagi menjadi dua bagian besar, yaitu mengenai e-learning community dan mengenai persepsi anggota eLC terhadap komputer atau gadget.

E-learning Community: Pengalaman sebagai Anggota E-Leaming Community

Manfaat yang dirasakan paling banyak oleh anggota eLC dari mengajar para dosen adalah dalam kaitannya dengan interaksi dengan dosen dan dari segi materi.

"Kalau dari saya sendiri, pertama say-kalau dari saya sendiri saya jadi lebih banyak belajar tentang sebuah program dan program lainnya dalam melakukan dalam sebuah forum yang berhasil kita lakukan kita bertukar pikiran dengan orang-orang lain sehingga kita dapat pengetahuan yang lebih yang sebelumnya kita nggak pernah tau, nggak cuma dari belajar kita sendiri aja." eLC1 [24459-24955]

Mahasiswa merasa kegiatan eLC menambah interaksi antara mereka dengan dosen, yang berdampak pada peningkatan kepercayaan diri dan peningkatan relasi.
"Jadi saya bisa mengembangkan kemampuan saya untuk berinteraksi dengan dosen yang mungkin sebelumnya saya merasa kurang percaya diri atau bingung, bagaimana berkomunikasi dengan dosen. Tapi setelah eee mengikuti elearning ini, eee... saya merasa bahwa berkomunikasi dengan dosen tidak semenakutkan yang saya kira sebelumnya. Saya juga mendapatkan eee ilmu seperti... eee... belajar Zotero dan juga Google Drive."eLC1 [2047-2452]

Kendala utama dalam proses mengajar di eLC adalah masalah penyesuaian waktu dengan dosen (masalah jadwal). Kendala lainnya adalah masalah teknis (koneksi internet dan komputer yang digunakan untuk mengajar), masalah pengetahuan pengajar sendiri, dan sifat dosen yang tidak mendukung dalam proses belajar-mengajar.

"Kalau menurut saya sih, yang saya alamin ya, masalah yang pertama kali itu pertama adanya di internet sama di komputernya. Jadi nggak jarang tuh kadang-kadang koneksi internet suka labil, mati nyala mati nyala sehingga bisa kalau kita udah liat pake Zotero atau GDrive itu nggak bisa dilakukan." eLC1 [8466-9219]

"Dan mungkin sedikit dukanya adalah ketika eee dosennya itu... kita udah janjian waktu, gitu. Tapi ternyata pada pas hari H dosennya itu eee entah nggak ada, entah cancel... itu jadi agak sedikit down sih.” eLC1 [3852-4056]

Secara umum anggota eLC berpendapat bahwa metode pengajaran e-learning kepada dosen secara privat cukup efektif karena lebih fokus dan lebih mudah untuk memahami keinginan dosen. Sistem pengajaran secara 
privat dianggap lebih efektif karena menunjang interaksi yang lebih baik antara anggota e-learning community dengan dosen penerima layanan:

"Kalau dari saya, saya lebih eee... saya rasa lebih baik yang meng-approach dosen satu per satu dan mengajari secara privat karena di situ dosen akan memilih-bisa leluasa bertanya, leluasa mengeksplor apa yang ingin mereka ketahui dan mereka pelajari dibandingkan ketika eee dosennya yang harus datang atau beberapa dosen diajar dalam waktu yang bersamaan." eLC1 [12139-12494]

Selain itu, keefektifan sistem pengajaran privat juga disebabkan oleh kemampuan masing-masing dosen yang berbeda sehingga membutuhkan bantuan privat.

"kalau menurut saya sistem pengajaran yang sekarang sudah cukup baik karena kemampuan setiap dosen tidak sama dan jika kita menerapkan sistem pengajaran di kelas besar yang satu orang mengajar satu- satu kelas dosen akan tidak efektif karena ya seperti tadi saya bilang, kemampuan dosennya tidak sama." eLC1 [15749-16050]

Meskipun demikian, beberapa anggota eLC berpendapat agar lebih baik menggunakan metode kedua dengan klinik. Klinik dibuka oleh eLC dengan menyediakan waktu pelatihan pada jam tertentu di ruang lab komputer dan dosen tinggal memilih waktu, dosen datang sendiri ke ruang pelatihan. Metode klinik mengatasi kendala sulitnya menentukan jadwal pertemuan dengan dosen.

"Untuk sistem pengajarannya saya rasa eee... kurang... kurang pas karena untuk mencari dosen satu per satu itu sungguh sulit dan saya lebih suka dengan metode yang terakhir, yang di... satu dosen diajak... beberapa dosen diajak masuk di satu ruangan dan kita berkumpul di situ beberapa orang mengajarkan saat itu juga. Karena kalau eee... karena kalau harus berte- dengan janji itu dokter-dokter itu biasanya eee nanti tiba-tiba ada pasien lah, ada acara apa... sedangkan kalau misalkan dari jam segini sampai jam segini eee ada di ruangan ini, silakan kalau mau datang ada orang di situ, gitu, mereka bisa kalau oh, lagi kosong nih, ya udah datang aja." eLC1 [11492-12135]

Saran dari anggota untuk e-learning community ke depannya antara lain terdapatnya sistem modul dan menggunakan gabungan dari metode privat dan klinik.

\begin{abstract}
"Kalau menurut saya lebih baik jika menerapkan duaduanya. Karena tidak semua materi memang bisa diajarkan untuk beberapa dosen sekaligus di kelas yang besar, tapi ada juga beberapa materi yang bisa. Kalau misalnya diajarkan secara serentak beberapa dosen sekaligus itu tidak masalah, tapi ak-tetap ada beberapa materi yang akan lebih baik jika diajarkan secara privat." eLC1 [12498-12868]
\end{abstract}

\section{Teknologi Informasi}

Anggota eLC menggunakan komputer atau gadgetsetiap hari, umumnya untuk kebutuhan yang berkaitan dengan kegiatan akademis, berkomunikasi, dan mengisi waktu luang.

"Eee kalau untuk saya, saya menggunakan gadget yang pasti setiap hari cuma ya... tiap hari pun itu ada jadwaljadwalnya lagi, jadi ada waktu saya pakai gadget buat main, ada waktu buat belajar, ada juga waktu untuk membuat-ngeberesin gadget itu sendiri, seperti itu." eLC1 [17922-18187]

\section{Computer Anxiety dan Computer Self-efficacy}

Anggota eLC merasa nyaman dan percaya diri dalam menggunakan komputer, terutama untuk kebutuhan sehari-hari. Beberapa mengatakan bahwa mereka kurang percaya diri jika diberi program baru atau diminta mengerjakan hal yang tidak familiar, tetapi mereka tetap berani mencoba menjalankan dengan lebih hati-hati atau memiliki inisiatif untuk mencari bantuan. Computer anxiety yang timbul pada anggota eLC terjadi bila mereka tidak cukup pengetahuan mengenai hal yang bersangkutan. Sikap ini beragam tergantung masing-masing pribadi, tetapi umumnya menyangkut software yang belum pernah digunakan sebelumnya.

\footnotetext{
"Tapi seandainya saya mencoba suatu program baru pada awalnya biasanya saya merasa sedikit... bisa dibilang sedikit... nervous karena di situ saya belum mengerti kinerja dari program yang baru akan saya pelajari saat itu. Dan saya juga tidak tahu efek apa yang ditimbulkan jika nanti saya salah mengoperasikan program yang baru saya pelajari tersebut." eLC1 [18989-19335]
}

Kenyamanan dan kepercayaan diri para anggota dalam menggunakan komputer adalah karena sudah memiliki cukup pengetahuan mengenai komputer. Para anggota 
berpendapat bahwa komputer adalah sesuatu yang bisa dipelajari, jadi tidak perlu ditakutkan.

"karena eеe... saya eеe cukup mengerti, maksudnya eеe... apa yang harus saya lakukan ketika terjadi sesuatu. Tapi kalau untuk mengatasi komputer yang tiba-tiba nge-hang atau misalnya eee rusak, sampai misalnya windows-nya rusak, saya juga eee tidak mengerti." eLC1 [20365-20619]

Perubahan sikap yang dirasakan anggota eLC setelah mengajar adalah perubahan dari aspek penguasaan materi. Sementara dari aspek persepsi terhadap komputer sebagian besar anggota merasa tidak ada perubahan.

"Ya, karena memang nggak ada perubahan. Meskipun saya mendapatkan ilmu yang baru tetapi kalau dipikir, nggak usah diberi pelatihan, kan bisa dicari... pokoknya bisa dicari di internet dengan sangat mudah. Secara umum persepsi saya terhadap komputer tidak ada perubahan yang signifikan." eLC1 [31425-31708]

Computer Anxiety, Computer Self-efficacy, dan Persepsi Dosen terhadap Pelatihan E-learning

Dari hasil wawancara dosen didapatkan data-data yang dibagi menjadi dua bagian besar, yaitu mengenai pengalaman belajar dengan eLC dan mengenai persepsi dosen terhadap komputer atau gadget.

Dosen merasakan manfaat dari pelatihan yang diadakan oleh eLC. Dari pelatihan e-learning, dosen merasa mendapat manfaat dari segi pengetahuan (materi) sehingga dapat mempermudah pekerjaan mereka.

"ya, pelatihan e-learningyang saya ikutin terus terang cuma baru 2 session ya, 2 session yang dalam arti menurut saya itu cukup singkat sekali ya. Walaupun dalam ya.. walaupun singkat tetapi ya bisa, bisa didapatkan sesuatu ya itu. Ee.. apalagi di.. dijalankan dalam waktu yang mungkin lebih lama atau bagaimana mungkin akan. manfaatnya akan lebih banyak." lecturer9 [203-560]

"ya kalau untuk saya sih materinya barangkali ee.. memang cocok untuk menunjang kewajiban saya sebagai dosen sih, yang tadi saya bilang di depan, untuk mengajar untuk melakukan, menulis sebuah artikel." lecturer3 [1932-2133]

Selain manfaat, dosen juga mengemukakan kendala yang dihadapi dalam mengikuti pelatihan elearning diantaranya dari segi teknis, kekhawatiran akan jadwal mahasiswa yang terganggu, motivasi, sampai cara mengajar mahasiswa. Kendala utama para dosen adalah sulitnya mencocokkan jadwal dengan berbagai pelatihan, termasuk pelatihan e-learning oleh eLC dengan mahasiswa. Kendala lainnya adalah dari segi materi, dosen merasa terkendala bila pengetahuan baru tentang suatu software yang telah dilatih eLC kurang memadai, dosen mengakui perlunya aplikasi langsung sehingga terpelihara dan lebih menguasai.

"Kendalanya adalah dalam... eee... ini, apa namanya, materinya. Kendala di materi ini menyangkut, ya, karena saya tidak langsung mengaplikasikan. Kalau langsung mengaplikasikan, dan saya menemukan langsung kesulitannya, dan Anda ada di sebelah saya, sangat senang karena ada malaikat penolong di sebelah saya. Saya harus cari-cari, di mana ini malaikat penolong saya * tertawa * ya. Kendalanya kendala waktu, itu saja, ya." lecturer1 [2900-3320]

Dosen merasa sistem pengajaran eLC dengan cara privat cocok diterapkan bagi dosen terutama yang berusia lanjut. Sistem pembelajaran secara privat dianggap lebih efektif, menyenangkan, dan dapat memenuhi kebutuhan pembelajaran e-learning setiap dosen yang berbeda-beda baik dari segi jadwal maupun materi, meski masih terkendala mengenai waktu.

"ee.. cocok sekali ya, soalnya jujur staf dosen itu ee.. banyak yang sibuk sekali yah gitu. Jadi mereka waktunya itu tidak sesuai dengan waktu yang ditetapkan MEU untuk kegiatan gitu loh, kegiatan e-learning. ..." lecturer7 [15012119]

Dosen menyarankan agar program eLC diberlakukan di FKUAJ dengan anggota eLC yang ditambah, materi dan jadwal pengajaran yang lebih cocok dengan dosen, penambahan jumlah pengajaran, dan adanya sistem assessment dan modul.

Terlepas dari frekuensi menggunakan komputer atau gadget yang berbeda-beda antardosen, semua dosen yang diwawancara menyatakan bahwa mereka menggunakan komputer untuk pekerjaan sehari-hari sehingga komputer sudah menjadi bagian dari hidup mereka. Penggunaan komputer dosen sehari-hari banyaknya berkaitan dengan pekerjaan dan jarang untuk entertainment. Secara keseluruhan dosen merasa nyaman dalam menggunakan komputer untuk kebutuhan sehari-hari. Meskipun dosen secara umum tidak menunjukkan computer anxiety, ada 
hal-hal spesifik yang mengganggu dosen dalam penggunaan komputer yaitu ketakutan akan merusak data pada komputer dan ketakutan akan virus.

"Yak. Jadi itu menolong ya. Kemudian kenapa saya khawatir? Nih, saya... saya punya sesuatu yang baru, soft file, saya mau masukkan ini. Kesatu, komputer saya udah penuh kali dengan segala berbagai... spacenya tinggal sedikit. Kedua, data-data saya dengan masuknya ini, ya bisa ngerusak nggak? Bisa kan? Itu kekhawatiran umum tidak?" lecturer1 [7318-7651]

Persepsi dosen yang secara umum baik dalam pemakaian komputer dikarenakan sudah terbiasanya dosen dalam menggunakan komputer, keyakinan (belief) pribadi, dan karena merasa memiliki bantuan bila dihadapkan dengan masalah yang tidak bisa ditangani sendiri.

"kan bisa nanya ke labkom, bisa nanya dokter .... Itu terus sama tanya-tanya orang, tanya Ibu Beth mungkin, tanya mahasiswa mungkin. Kalau ga ya cari-cari ini aja, cari-cari di internet caranya gimana. Kalau uda BT ya uda berhenti, ga usah dipakai lagi. Haha, kalau misalnya ga bisa dapat jawaban gitu ya. Mungkin lebih baik pakai cara lain, karena buang-buang waktu juga gitu, waktu kita kan terbatas gitu." lecturer7 [3892-4348]

Dosen merasakan perubahan kenyamanan dan kepercayaan diri dalam hal materi yang diajarkan (hanya software tertentu). Mayoritas dosen tidak merasakan perubahan dalam persepsi umum mereka mengenai komputer, karena isu-isu yang mereka hadapi tidak berhubungan dengan apa yang dilatihkan oleh eLC.

"Kekhawatiran saya kan menyangkut apa namanya, USB virus... itu... ya tetap aja segitu kuatirnya. Kalau kamu kasih USB yang ada virusnya, "Eh, kamu udah... ini virusnya ada apa enggak?" *tertawa* Gitu kan, saya tetap aja kuatir. Kalau misalkan diinstall komputer baru, "Data saya rusak nggak?" Tetap aja kuatir, gitu. Ya. Jadi, ya sama aja kekuatirannya. Tetap begitu, ya." lecturer1 [10399-10772]

\section{Persepsi Dosen terhadap Komputer}

Pada data kuantitatif dosen terjadi penurunan skor CARS yang bermakna dari yang ketiga ke skor yang keempat. Computer anxiety dipengaruhi oleh perceived usefulness, perceived ease of use, subjective norm, dan facilitating conditions yang mencakup antara lain adanya pelatihan, adanya bantuan, dan adanya informasi yang memadai. ${ }^{18}$ Penelitian lain ${ }^{19}$ menunjukkan korelasi negatif antara computer anxiety dengan penggunaan computer; sementara ada korelasi positif antara pengalaman menggunakan komputer dan penggunaan komputer dengan computer self-efficacy. Pelatihan komputer telah terbukti meningkatkan computer literacy. ${ }^{20}$ Peningkatan computer literacy ini secara langsung akan meningkatkan persepsi terhadap kegunaan yang dirasakan (perceived usefulness) dan persepsi kemudahan penggunaan komputer (perceived ease of use). Adanya mahasiswa anggota eLC yang siap melayani dosen apabila mereka membutuhkan bantuan juga menambah facilitating conditions sehingga computer anxiety dosen berkurang. Computer anxiety berkorelasi negatif dengan computer self-efficacy sehingga dengan penurunan computer anxiety, computer selfefficacy diharapkan membaik. ${ }^{17,19}$ Peningkatan computer self-efficacy memang ditemukan pada kelompok dosen dan anggota eLC tetapi tidak signifikan.

Peningkatan computer self-efficacy yang tidak bermakna mungkin disebabkan oleh beberapa hal. Pada saat pembentukan eLC, rencana tim peneliti adalah memperbaiki sikap dosen-dosen yang kurang sadar atau bahkan takut akan teknologi komputer agar memperoleh bimbingan sehingga terjadi perubahan sikap atau paling sedikit persepsi terhadap e-learning. Meskipun demikian, pada kenyataannya dosen yang datang untuk meminta pelayanan justru dosen-dosen yang sadar komputer dengan persepsi yang baik; hal ini tercermin dari skor CARS dan CSE para dosen ini. Selain itu, tiadanya perubahan persepsi ini didukung oleh data kualitatif yang menyatakan mereka telah terbiasa menggunakan komputer untuk kebutuhan sehari-hari dan memiliki persepsi yang secara keseluruhan baik terhadap komputer. Dapat disimpulkan bahwa dengan telah terbiasanya dosen menggunakan komputer dalam keseharian mereka, dosen juga telah menguasai dasardasar untuk menggunakan komputer. Pelatihan yang diberikan oleh eLC bersifat spesifik dan tidak menyentuh hal-hal yang advanced seperti troubleshooting, menulis program, atau penyimpanan software. Dapat diperkirakan skor computer self-efficacy tidak berubah karena penyataanpernyataan pada kuesioner yang bersifat mendasar sudah dikuasai dari awal, dan pernyataan-pernyataan yang bersifat advanced tidak tersentuh oleh pelatihan. 
Peningkatan kemampuan yang dirasakan dosen bisa jadi hanya cukup untuk menurunkan anxiety, tetapi tidak mengubah persepsi dosen terhadap kemampuan mereka sendiri. Sebagai tambahan pada data kualitatif dosen juga menyatakan mendapat manfaat secara materi (pengetahuan), meskipun hal ini tergolong peningkatan self-efficacy, tetapi tidak tercermin dari skor kuesioner CSE.

Apabila dilihat dari skor CARS dan CSE para dosen, hal ini sudah cukup meyakinkan bahwa dosen siap untuk mengimplementasikan e-learning. Skor CARS dosen ( \pm 34 - 38) tidak menunjukkan kekawatiran, sedangkan skor CSE juga sudah tinggi ( \pm 118 - 124); kedua kondisi tersebut didukung oleh data kualitatif. Individu dengan computer anxiety yang rendah dan computer self-efficacy yang tinggi lebih terbuka akan teknologi komputer (computer acceptance), menggunakan komputer lebih banyak, ${ }^{21,22}$ dan memiliki motivasi yang tinggi untuk belajar. ${ }^{23}$ Jika dengan kenyataan hasil penelitian ini dan bila masih didapati perubahan yang terhambat dalam e-learning, maka tim peneliti berpendapat bahwa dosen perlu diberi dorongan dari institusi untuk mulai menerapkan elearning.

\section{Persepsi Anggota E-learning Community terhadap Komputer}

Skor CARS dan CSE anggota eLC sebelum pelatihan masing-masing: 38,83 dan 119,25. Bila dibandingkan dengan penelitian-penelitian sebelumnya, maka tabel 8 merangkumkan kondisi ini.

Tabel 8. Tabel perbandingan nilai rerata CARS dan CSE antar penelitian

\begin{tabular}{|c|c|c|c|}
\hline & Subjek Penelitian & Mean CARS & Mean CSE \\
\hline Penelitian ini & Mahasiswa anggota eLC & 38,83 & 119,25 \\
\hline Durndell dan Haag ${ }^{17}$ & $\begin{array}{l}\text { Mahasiswa universitas di } \\
\text { Romania }\end{array}$ & 37,7 & 107,3 \\
\hline Sam, Othman, dan Nordin ${ }^{24}$ & $\begin{array}{l}\text { Mahasiswa Universiti Malaysia } \\
\text { Sarawak }\end{array}$ & 63,41 & 112,10 \\
\hline
\end{tabular}

Sam, Othman, dan Nordin mengklasifikasikan skor CARS penelitian mereka ${ }^{63,41}$ sebagai moderate (sedang) dan skor CSE $(112,10)$ sebagai high (tinggi), sehingga skor CARS anggota e-learning community dapat dikatakan rendah dan skor CSE-nya dapat dikatakan tinggi.

Hasil tes Friedman dan tes post-hoc Wilcoxon memberikan informasi adanya penurunan skor CARS secara signifikan dari pengambilan data pertama ke pengambilan data keempat. Hal ini didukung oleh data kualitatif yang menunjukkan beberapa anggota eLC selain mendapat manfaat dari segi materi juga merasakan persepsi mereka membaik dalam menggunakan komputer. Mayoritas anggota tidak merasa ada perubahan, tetapi hal ini tidak terbukti dari hasil analisis kuantitatifnya.

Dari data kualitatif dapat diketahui bahwa beberapa anggota eLC merasa pikiran mereka terbuka terhadap piranti-piranti lunak baru setelah membimbing para dosen. Hal yang biasanya mereka takutkan dalam kaitannya dengan pembelajaran piranti lunak baru tidak lagi terlihat sangat menakutkan. Ini adalah hasil dari keharusan eLC mempelajari ragam applikasi yang pada awalnya belum mereka kuasai, seperti Google Drive, Prezi, dan Zotero ${ }^{\mathrm{TM}}$.

Mayoritas anggota merasa tidak ada perubahan dalam persepsi. Anggota-anggota ini mengindikasikan bahwa dari awal persepsi mereka sudah baik dan pelatihan $e$ leaming dalam eLC hanya menambah pengetahuan, tidak mengubah persepsi, seperti kutipan berikut:

"Kalau menurut saya sendiri persepsinya juga tidak berubah, karena sebelum dan sesudah saya direkrut menjadi e-learming ini sebenarnya saya udah bisa semuanya, itu eee... nggak... nggak gitu ngefek." LC1 [32585-32890]

Tidak berubahnya nilai kuantitatif CSE dapat dijelaskan seperti tidak berubahnya nilai CSE dosen. Dari hasil penelitian kuantitatif dan kualitatif diketahui bahwa anggota eLC telah terbiasa menggunakan komputer untuk pekerjaan sehari-hari, bahkan untuk kesenangan pribadi (leisure). Penggunaan komputer dan pengalaman 
menggunakan komputer ini menjelaskan skor CA dan CSE mereka yang menunjukkan persepsi yang baik terhadap komputer. ${ }^{19}$ Para anggota menyatakan percaya diri dan nyaman menggunakan komputer, dengan pengecualian pada saat-saat tertentu.

Dengan hasil data kuantitatif dan kualitatif tersebut dapat ditarik kesimpulan bahwa anggota eLC telah menguasai keterampilan-keterampilan dasar menggunakan komputer sehingga sudah tidak memerlukan perbaikan lagi. Adapun hal-hal yang belum mereka kuasai merupakan materi lanjutan yang lebih kompleks misalnya sistem informatika atau yang berkaitan dengan hardware. Materi-materi lanjutan ini tidak dilatihkan dalam eLC, sehingga persepsi anggota dalam hal tersebut pun tidak berubah.

Peneliti berasumsi bahwa jumlah sampel yang kecil juga ikut menyebabkan inkonsistensi antara skor CARS dan skor CSE. Data kuantitatif dalam penelitian ini didukung oleh data kualitatif untuk menjamin validitasnya, tetapi peneliti menyarankan untuk penelitian berikutnya agar jumlah sampel diperbesar karena populasi yang diteliti bersifat heterogen. ${ }^{26,27} \mathrm{Hal}$ ini dapat dilakukan dengan cara penjaringan peserta dosen dan pendataan peserta sebelum program dimulai.

Perbandingan antara Perubahan Nilai Computer Anxiety Rating Scale (CARS) dan Computer Selfefficacy (CSE) dosen dengan perubahan nilai CARS dan CSE anggota eLC

Perubahan nilai CARS dan CSE dosen tidak berbeda saat dibandingkan dengan perubahan nilai CARS dan CSE anggota eLC. Dari tidak adanya perbedaan tersebut dapat ditarik kesimpulan bahwa kecepatan perubahan persepsi dosen sama dengan kecepatan perubahan persepsi mahasiswa dalam hal computer anxiety dan computer selfefficacy.

Peneliti menduga bahwa tidak adanya perbedaan ini disebabkan oleh karakteristik dosen dan anggota eLC yang mirip dalam kaitan persepsi penggunaan komputer. Kedua kelompok menggunakan komputer dan gadget dalam kehidupan sehari-hari serta merasa nyaman dalam kegiatan tersebut. Penggunaan komputer anggota eLC lebih luas dibandingkan dosen (anggota komunitas lebih banyak menggunakan perangkat komputer/gadget untuk leisure daripada dosen) dan hal ini memang tercermin dari skor CARS e-learning community yang lebih rendah dan skor CSE yang lebih tinggi. ${ }^{19,25}$ Kedua kelompok menunjukkan skor CARS dan CSE awal yang mengindikasikan persepsi baik dalam menggunakan komputer. Computer anxiety kedua kelompok merujuk ke hal-hal yang spesifik saja, meskipun hal yang dimaksud berbeda antara kelompok dosen dan kelompok anggota eLC; anxiety dosen berkaitan dengan virus, sedangkan anggota eLC mengenai piranti keras dan piranti lunak yang belum mereka kuasai.

Penelitian yang dilakukan oleh Smith pada tahun $2013^{29}$ sudah sempat memperdebatkan apakah dosen benarbenar "digital immigrants". Penelitian tersebut menyimpulkan bahwa perbedaan antara mahasiswa dengan anggota fakultas lain (termasuk dosen) sebagai "digital natives"-"digital immigrants" terlalu dilebihlebihkan dan sebenarnya tidak signifikan dalam kehidupan. Teori tersebut mungkin dapat diaplikasikan ke sebagian besar dosen di FKUAJ, tetapi pada kenyataannya dari sistem pengajaran dosen ke mahasiswa di kampus masih ada saja dosen yang benarbenar "digital immigrants". Dosen-dosen "digital immigrants" ini, yang diharapkan menjadi target pelatihan eLC, justru tidak datang untuk menerima pelatihan sehingga tidak terwakilkan datanya dalam penelitian.

Adapun perbedaan antara anggota eLC dengan kelompok dosen yang menjadi subyek penelitian dapat terlihat dari hasil penelitian kualitatif. Banyak dosen yang menyatakan bahwa ketika mereka menemui masalah, mereka akan bertanya kepada orang lain untuk mengatasi masalah tersebut. Berbeda dengan anggota eLC yang selain bertanya, juga dapat mengatasi masalah dengan mencari informasi secara mandiri lewat internet.

\section{KESIMPULAN}

(1) Dosen terbagi menjadi dua kelompok dengan perubahan persepsi yang berbeda, yaitu kelompok dosen yang merasa proses belajar dengan e-learning community memberi mereka persepsi yang lebih baik terhadap komputer dan kelompok dosen yang merasa tidak mengalami perubahan persepsi, (2) Anggota e-learning community terbagi menjadi dua kelompok dengan perubahan persepsi yang berbeda, yaitu kelompok 
anggota minoritas yang merasa pengalaman dalam eLC memberi mereka persepsi yang lebih baik terhadap komputer dan kelompok anggota mayoritas yang merasa tidak mengalami perubahan persepsi, (3) Perubahan persepsi antar pengambilan data dosen dan anggota eLC tidak berbeda secara signifikan, yang berarti kesiapan dosen dalam menerima ilmu baru dalam teknologi sama dengan anggota komunitas.

\section{DAFTAR SINGKATAN}

$$
\begin{aligned}
& \text { eLC : e-learning community } \\
& \text { CA : computer anxiety } \\
& \text { CARS : computer anxiety rating scale } \\
& \text { CSE : computer self-efficacy }
\end{aligned}
$$

\section{COMPETING INTEREST}

Tidak ada competing interest apapun dalam penelitian ini. Dana penelitian berasal dari dana fakultas. Penelitian ini sudah disetujui oleh Komisi Etik Fakultas Kedokteran Universitas Katolik Indonesia Atma Jaya, Jakarta.

\section{INFORMASI KONTRIBUSI TENTANG PENGARANG}

JA adalah peneliti utama dalam proyek elearning community ini. JA mengumpulkan data dan menganalisisnya serta menuliskannya dalam laporan. ER adalah penggagas utama elearning community, melakukan kajian bersama pada saat analisis, memberikan masukan untuk laporan serta melakukan finalisasi artikel ini.

\section{ACKNOWLEDGEMENTS}

Terima kasih kepada para mahasiswa anggota e-learning community. Penulis juga mengucapkan mengucapkan terima kasih kepada Intan Permata Sari yang telah bersama-sama dengan Penulis menjalankan program elearning community serta membantu pengambilan data penelitian.

\section{DAFTAR PUSTAKA}

1. Horton W. e-Learning by Design. John Wiley and Sons; 2011. 638 p.

2. Lau F, Bates J. A Review of e-Learning practices for undergraduate medical education. Journal of Medical Systems. 2004 Feb;28(1):71-87.

3. Abdelhai R, Yassin S, Ahmad MF, Fors UG. An elearning reproductive health module to support improved student learning and interaction: a prospective interventional study at a medical school in Egypt. BMC Medical Education. 2012;12(1):11.

4. Jamero DJ, Borghol A, Mihm L. Comparison of computer-mediated learning and lecture-mediated learning for teaching pain management to pharmacy students. Am J Pharm Edu. 2009;73(1):5.

5. Varghese J, Faith M, Jacob M. Impact of e-resources on learning in biochemistry: first-year medical students' perceptions. BMC Medical Education. 2012;12(1):21.

6. Morgulis Y, Kumar RK, Lindeman R, Velan GM. Impact on learning of an e-learning module on leukaemia: a randomised controlled trial. BMC Medical Education. 2012;12(1):36.

7. Kononowicz AA, Krawczyk P, Cebula G, Dembkowska M, Drab E, Fraczek B, et al. Effects of introducing a voluntary virtual patient module to a basic life support with an automated external defibrillator course: a randomised trial. BMC Medical Education. 2012;12(1):41.

8. Wagner N, Hassanein K, Head M. Who is responsible for e-learning success in higher education? A stakeholders' analysis. Journal of Educational Technology \& Society. 2008;11(3):n/a.

9. Prensky M. Don't bother me mom - I'm learning! St. Paul: Paragon House; 2006.

10. Prensky M. Listen to the natives. Educ Leadership. 2006;63(4):8-13

11. Rukmini E, Linarto R. Studi mengenai perspektif mahasiswa dan staf pengajar terhadap e-learning. Universitas Katolik Indonesia Atma Jaya Jakarta: Fakultas Kedokteran; 2012.

12. Chen C, Liu C-C. A case study of peer tutoring program in higher education. Research in Higher Education Journal. 2011 Jun;11:1-10.

13. Hauer KE, O'Brien BC, Hansen LA, Hirsh D, Ma $\mathrm{IH}$, Ogur B, et al. More is better: students describe successful and unsuccessful experiences with teachers differently in brief and longitudinal relationships. Acad Med. 2012 Oct;87(10):1389-96.

14. Glynn LG, MacFarlane A, Kelly M, Cantillon P, Murphy AW. Helping each other to learn - a process evaluation of peer assisted learning. BMC Medical Education. 2006 Mar 8;6(1):18.

15. Heinssen Jr. RK, Glass CR, Knight LA. Assessing computer anxiety: Development and validation of the Computer Anxiety Rating Scale. Computers in Human Behavior. 1987;3(1):49-59.

16. Torkzadeh G, Koufteros X. Factorial validity of a computer self-efficacy scale and the impact of computer training. Educ Psychol Meas. 1994;54(3):813-21. 
17. Durndell A, Haag Z. Computer self efficacy, computer anxiety, attitudes towards the Internet and reported experience with the Internet, by gender, in an East European sample. Computers in Human Behavior. 2002 Sep;18(5):521-35.

18. Teo T, Lee C b., Chai C. Understanding pre-service teachers' computer attitudes: applying and extending the technology acceptance model. J Comput Assist Lear. 2008;24(2):128-43.

19. Fagan MH, Stern N, Wooldridge BR. An Empirical Investigation into the Relationship Between Computer Self-Efficacy, Anxiety, Experience, Support and Usage. J Comput Inform Syst. 2003 Winter / 2004;44(2):95-104.

20. Ktoridou D, Eteokleous-Grigoriou N. Developing digital immigrants' computer literacy: the case of unemployed women. Campus-Wide Information Systems. 2011;28(3):154-63.

21. Compeau DR, Higgins CA. Computer self-efficacy: Development of a measure and initial test. MIS Quarterly. 1995;19(2):189.

22. Venkatesh V. Determinants of perceived ease of use: Integrating control, intrinsic motivation, and emotion into the technology acceptance model. Inform Syst Res. 2000;11(4):342-65.
23. Colquitt JA, LePine JA, Noe RA. Toward an integrative theory of training motivation: A meta-analytic path analysis of 20 years of research. J Appl Psychol. 2000;85(5):678-707.

24. Sam HK, Othman AEA, Nordin ZS. Computer SelfEfficacy, Computer anxiety, and attitudes toward the internet: A study among undergraduates in Unimas. Journal of Educational Technology \& Society. 2005;8(4):205-19.

25. Malliari A, Korobili S, Togia A. IT self-efficacy and computer competence of LIS students. Electron Libr. 2012;30(5):608-22.

26. Hudson Z. Sample size, power and effect size - What all researchers need to know. Physical Therapy in Sport. 2009; 10(2):43-4.

27. Lenth RV. Some practical guidelines for effective sample size determination. The Am Stat. 2001;55(3):187-93.

28. Smith E. Are adult educators and learners "Digital Immigrants"? Examining the evidence and impacts for continuing education. Canadian Journal of University Continuing Education [Internet]. 2013 [cited 2013 Oct 24];39(1). Available from: http:// ejournals.library.ualberta.ca/index.php/cjuce-rcepu/ article/view/20722 